\title{
Comparison of Antimicrobial and Antioxidant Activities by Different Extraction Methods in Korean Bamboos
}

\author{
Hwan-Seok Choi ${ }^{1,2}$, Gwui-Cheol Kim ${ }^{3}$, and Hyun-Jae Shin ${ }^{1}$ *
}

접수: 2012년 4월 3일 / 게재승인: 2012년 4월 20일

(C) 2012 The Korean Society for Biotechnology and Bioengineering

\begin{abstract}
To develop potential cosmetic ingredients with antimicrobial and antioxidant activities of 4 Korean bamboo species (P. bambusoides, P. nigra var. henonis, P. pubescens and Sasa coreana) using three different extraction methodswater, ethanol and supercritical fluid extraction. Antimicrobial activities and DPPH assay have been examined. Among the antimicrobial activities against two test strains, Escherichia coli and Staphylococcus aureus, ethanol extracts of 3 bamboo trees, $P$. bambusoides, $P$. nigra var. henonis, and $P$. pubescens, showed stronger than those of supercritical extracts. However, 4 bamboo supercritical extracts showed dose-dependent increase in antioxidant activity by DPPH assay. These results suggest that water fraction of bamboo extracts may be useful for the cosmetic ingredient with low cytotoxicity.
\end{abstract}

Keywords: Bamboo extracts, Different extraction methods, Antimicrobial activity, Antioxidative activity

\footnotetext{
${ }^{1}$ 조선대학교 생명화학공학과

${ }^{1}$ Department of Chemical \& Biochemical Engineering, Chosun University, Gwangju 501-759, Korea

Tel: +82-62-230-7518, Fax: +82-62-230-7226

e-mail:shinhj@chosun.ac.kr

2 양지엔텍 부설연구소

${ }^{2}$ Yang-ji Entech. Co., Damyang 517-803, Korea

${ }^{3}$ 전남나노바이오연구센터

${ }^{3}$ Department of Technical Development, Jeonnam Nano Bio Research Center, Jangseong 515-839, Korea
}

\section{1. 서론}

기존의 추출법에 비하여 초임계 추출법은 초임계 유체의 장 점을 이용한 증류 (distillation)와 추출 (extraction)의 원리가 같이 적용되는 복합 기술의 성격을 갖기 때문에 화학공정 중 분리공정이 설비비용과 운전비용의 $60 \sim 70 \%$ 를 차지함을 고 려할 때 상당히 경제적인 공정방법이다. 초임계 유체는 압력 온도의 조작에 의하여 고밀도 상태에서 저밀도 상태의 어떤 조건 설정도 가능하기 때문에 분획 및 분리 등의 선택성이 뛰어나서 고순도의 제품을 얻을 수 있고, 추출 용매를 손실 없이 거의 완전하게 회수할 수 있으며, 잔존 용매가 없는 정제 물을 얻을 수 있다 $[1,2]$. 또한 초임계 유체를 이용한 추출 은 높은 용해력, 물질 이동과 열 이동이 빠르고, 낮은 점도, 높은 확산계수 그리고 낮은 표면장력으로 인한 미세공으로 빠른 침투성 등과 같은 초임계유체의 장점을 이용하여 기존 의 반응 및 분해, 추출, 증류, 결정화, 흡수, 흡착, 건조, 세정 등의 공정에서의 저효율, 저품질, 저속, 환경에 대한 악영향 등과 같은 기술적 어려움을 해결할 수 있는 새로운 혁신기 술로서 주목받고 있다. 뿐만 아니라 초임계 유체 추출은 제 품생산 공정 내에서 각종 오염원의 발생을 원천적으로 방지 하거나 최소화할 수 있을 뿐 아니라 인간의 건강과 환경에 대한 유해성을 원천적으로 방지함으로써 전통적인 제품 생산 기술에 대비하여 경제적 이득을 가져올 수 있는 첨단 분리 기술의 하나이다. 따라서 지금까지 천연추출물을 얻어내기 위해 사용하는 대부분의 유기용매가 할로겐족 탄화수소가 주종을 이루고 있고 이들은 인화성, 위험성, 유독성, 발암성 의 가능성이 있는 것으로 알려지면서 이들을 사용하는데 대 한 규제가 강화되고 있으며, 동시에 사용 후의 유기용매를 재생하는데 드는 높은 비용 등으로 인하여 천연물 추출정제 
Table 1. Extraction conditions of each bamboo species by supercritical extraction

\begin{tabular}{lccccc}
\hline \multicolumn{1}{c}{ Species } & Temp. $\left({ }^{\circ} \mathrm{C}\right)$ & Pressure $\left(\mathrm{kg} / \mathrm{cm}^{2}\right)$ & Modifier ratio $\left(\mathrm{CO}_{2}:\right.$ ethanol) & Extraction Time $(\mathrm{min})$ & Flow rate $(\mathrm{mL} / \mathrm{min})$ \\
\hline Phyllostachys pubescens & 50 & 400 & $80: 20$ & 100 & 3 \\
Sasa coreana & 50 & 400 & $80: 20$ & 100 & 3 \\
Phyllostachys bambusoides & 50 & 400 & $80: 20$ & 80 & 2 \\
Phyllostachys nigra var. henonis & 50 & 400 & $80: 20$ & 80 & 2 \\
\hline
\end{tabular}

산업의 성장을 방해하는 요인으로 작용하여 왔는데 기존 합성 물질의 경쟁력을 억제하면서 소비자의 선호도와 각종 규제를 피할 수 있으며 경비측면에서도 경쟁력이 있는 대체 추출 기술로서 전통적인 유해매체를 사용하는 분리 추출기 술을 대신하는 “초임계 유체 추출 기술”이다. 이와 같은 초임 계 유체 추출기술은 기존의 기술로는 분리가 어려웠던 이성 질체, 열변성 혼합물의 분리, 고분자물질의 정제, 천연식물 로부터 의약, 향료와 같은 유효성분의 분리 등을 비롯해서 에너지 절약형 무공해 공정개발 등 그 응용범위가 넓으며, 최근 상업화가 활발히 진행되는 첨단 분리 기술의 하나이 다 [2,3]. 한편, 최근에는 국제적으로 건강에 해로운 잔존용 매에 대한 규제가 강화되고 환경에 부담을 주는 용제 배출 제한이 엄격해 지므로 이를 해결하기 위해서 더욱 더 에너 지를 많이 사용하여 분리정제를 해야 하는 실정이다. 국내에 서도 건강에 대한 관심이 높아지면서 다이어트 식품, 잔존 유 해용매가 없는 녹색식품에 대한 요구가 급증하고 있다. 따라 서 이산화탄소를 이용한 초임계 추출기술은 천연물이나 식품 에 적용하면 인체에 무해한 원료 및 제품을 생산하여 제품의 부가가치를 높일 수 있다.

대나무는 대나무는 벼과 (Gramineae)에 속하는 식물로 한국, 일본, 중국 등 동남아시아에 주로 분포한다. 벼과 중 가장 키가 큰 식물로 높이 $30 \mathrm{~m}$, 지름 $30 \mathrm{~cm}$ 내외에 달한다. 줄기는 땅속을 옆으로 뻗어가는 근경으로부터 직립하며, 둥 글며 속이 비어있다. 대나무 열수 및 용매추출법에 의한 추 출물의 생리활성 물질과 다양한 약리작용에 대한 보고가 있다 [4-6]. 대나무 추출물은 flavone glycosides, phenolic acids, coumarin lactones, anthraquinones, amino acids 등을 함유한다 [7-10]. 대나무 잎에는 플라보노이드 성분이 많 이 함유되어 있어 항산화, 항노화 및 항균 활성을 나타냄에 따라, 약제 보조제, 미용향장소재 및 식품 첨가물 등으로 사용되고 있다 [11-14]. 현재까지 대나무 추출물의 생리활성 에 관한 연구는 대나무 잎이 활성산소 제거 효소의 활성을 증대시켜 항암 효과를 나타낸다는 연구 [17]를 비롯하여 국내 자생 왕대, 솜대, 맹종죽 및 조릿대 또는 오죽의 항산 화 효과 [18], 조릿대 잎 추출물에 의한 비만 및 대사증후군 억제 효과 $[19,20]$ 등에 대한 연구가 이루어져 왔다. 이들 대부분의 연구는 대나무의 열수 및 용매추출물에 대한 생 리활성을 확인한 연구로 초임계 추출방법을 적용한 연구는 거의 없는 실정이었다.

따라서 본 연구에서는 향후 미용향장소재로서의 기능성 을 파악하기 위하여 국내 자생 대나무 4종에 대한 초임계 추출방법을 적용한 대나무 초임계 추출물의 항균 및 항산화 특성을 확인하고 이를 추후에 화장품 원료물질로 이용하기 위한 기초자료로 활용하고자 하였다.

\section{2. 재료 및 방법}

\section{1. 실험 재료}

실험에 사용된 대나무는 전남 담양군 담양읍 및 용면 일대 에 자생하는 담양산 대나무를 사용하였으며, 채취한 대나무 는 왕대 (Phyllostachys bambusoides), 솜대 (P. nigra var. henonis), 맹종죽 (P. pubescens) 및 신이대 (Sasa coreana) 등 4종을 대상으로 하였으며, 채취한 대나무는 깨끗한 물로 수세한 후 잎과 줄기 부분을 분리하여 7일간 자연 건조하여 대나무 파쇄기 (SUIN, Korea)를 이용하여 $50 \mathrm{~mm}$ 이하의 크기로 분쇄하여 추출에 사용하였다.

\section{2. 추출방법}

4종의 대나무 종류에 대한 추출방법별 비교 연구를 위하여 용매추출은 ethanol (94\%) 4 L에 자연 건조시킨 대나무 $1.0 \mathrm{~kg}$ 의 비율로 12 시간 동안 상온 추출하고 rotary evaporator (EYELA, Japan)를 이용하여 농축한 시료를 사용하였다. 열수 추출물은 자연 건조시킨 대나무 잎과 줄기를 2 차 증 류수 $4 \mathrm{~L}$ 에 $1.0 \mathrm{~kg}$ 를 $70^{\circ} \mathrm{C}$ 하에서 12 시간 추출하고 rotary evaporator를 이용하여 농축한 시료를 사용하였다.

대나무의 초임계 유체 추출물의 획득은 유용성분의 추출 을 위해 전남나노바이오연구센터 (JNBC)가 보유한 초임계 이산화탄소 추출장비 (Ilshin autoclave Co., Ltd., Korea)를 이용하여 추출을 진행하였다. 대나무 4종에 대한 초임계유체 추출은 추출물질을 추출바스켓에 넣고 압력을 서서히 올리 면서 목표압력인 $400 \mathrm{bar}$ 와 목표 온도 $50^{\circ} \mathrm{C}$ 로 올려 추출 조 건을 만족 시킨 후 실행하였다.

초임계 유체 장치 내에서 목표 압력과 온도가 설정되면 1 분 동안 순수 초임계 $\mathrm{CO}_{2}$ 유체를 흘려주고 이후 보조용 매인 에탄올을 $2 \mathrm{~mL} / \mathrm{min}$ 유량으로 60 분 동안 흘려주면서 추출을 실행하였다. 각 대나무 종에 대한 초임계 유체 추출 조건은 Table 1 과 같다.

\section{3. 항균활성}

전남 담양산 대나무 4종 (왕대, 솜대, 맹종죽, 신이대)의 초임 계 유체 추출물의 항균활성측정은 paper disc $(8 \mathrm{~mm}$, Toyo Roshi Kaisha, Japan)를 이용한 disc 확산법으로 측정하였 다. 한국생명공학연구원으로 분양받은 공시균주들을 액체배 지 $20 \mathrm{~mL}$ 에 접종한 후 적정 온도에서 24시간 배양하였다. 멸균된 생리식염수 $(0.85 \% \mathrm{NaCl})$ 에 O.D. $=0.1$ 로 희석된 균액을 평판배지에 도말하고 각각의 추출물 시료를 $10^{-1}$, $10^{-2}$ 및 $10^{-3}$ 으로 희석하여 paper disc에 $50 \mu \mathrm{L}$ 씩 흡수 건조 시킨 후 24시간 배양하여 disc 주위에 형성된 clear zone의 크기 $(\mathrm{mm})$ 를 항균활성으로 측정하였다. 


\subsection{DPPH 소거능에 따른 전자공여작용의 측정}

대나무 초임계 추출물의 항산화적 특성은 Perez 등 [26]의 방법에 따라 96 well plate에 ethanol에 녹인 $100 \mu \mathrm{M}$ DPPH 용액 $180 \mu \mathrm{L}$ 와 대나무 추출액을 최종 농도가 $2,6,12,20,60$, $120,200,1200 \mu \mathrm{g} / \mathrm{mL}$ 농도로 각각 $20 \mu \mathrm{L}$ 씩 가하고 차광 상태 에서 $37^{\circ} \mathrm{C}$ 에서 20 분간 배양한 후 UV-VIS Spectrophotometer (UV-1240, Shimadzu, Japan)를 이용하여 $517 \mathrm{~nm}$ 에서 흡광 도를 측정하였다. 각 추출물의 저해율은 3 회 반복 실험을 통 하여 얻은 값의 평균값으로 측정하였다.

\section{3. 결과 및 고찰}

\section{1. 항균특성}

대나무 4종에 대한 각 추출방법별 항균적 특성은 Fig. 1 과 Fig. 2 와 같다. 대나무 추출물의 항균성은 전반적으로 ethanol 추출물이 두 공시균주에 대하여 열수 및 초임계 추출물과 비교하여 우수한 항균력을 보이는 것으로 나타났다. 그람 음성균 E.coli에 대한 항균력에서는 3종의 대나무 (맹종 죽, 솜대, 왕대)에서 용매추출물이 강한 항균력 (clear zone $12 \mathrm{~mm}$ 이상)을 보인 반면에, 신이대의 경우는 초임계 추출 물이 다른 추출물에 비하여 가장 강한 항균력 $(14 \mathrm{~mm})$ 을 나타내어 대나무 종류에 따른 차이를 나타내었다. 그람 양 성균 S.aureus에 대해서도 E.coli에서와 같이 유사한 경향 을 나타내었다. 이러한 특성은 대나무 종류에 따라 적절한 추출방법을 적용하여 고유한 기능성 소재를 확보하는데 효 과적일 것으로 판단되었다. Huang [13]과 Chung 등 [16]은

Species
Phyllostachys
pubescens

Fig. 1. Comparison of antimicrobial activities against $E$. coli by different extraction methods in Korean bamboos.
대나무 잎 추출물이 식품미생물 Vibrio parahaemolyticus, Pseudomnas aeruginosa, Salmonella typhimurium 등에서 항균력을 나타내었다고 보고하였으며, 또한, 왕대, 솜대 및 맹종죽 잎과 줄기의 열수추출물이 S. aureus에 높은 항균 력을 나타내었다고 보고하였는데, 본 실험의 에탄올 추출 물의 경향과 차이를 나타내었다. 이는 대나무 종류에 따른 추출방법의 차이에서 비롯된 것으로 판단되었다.

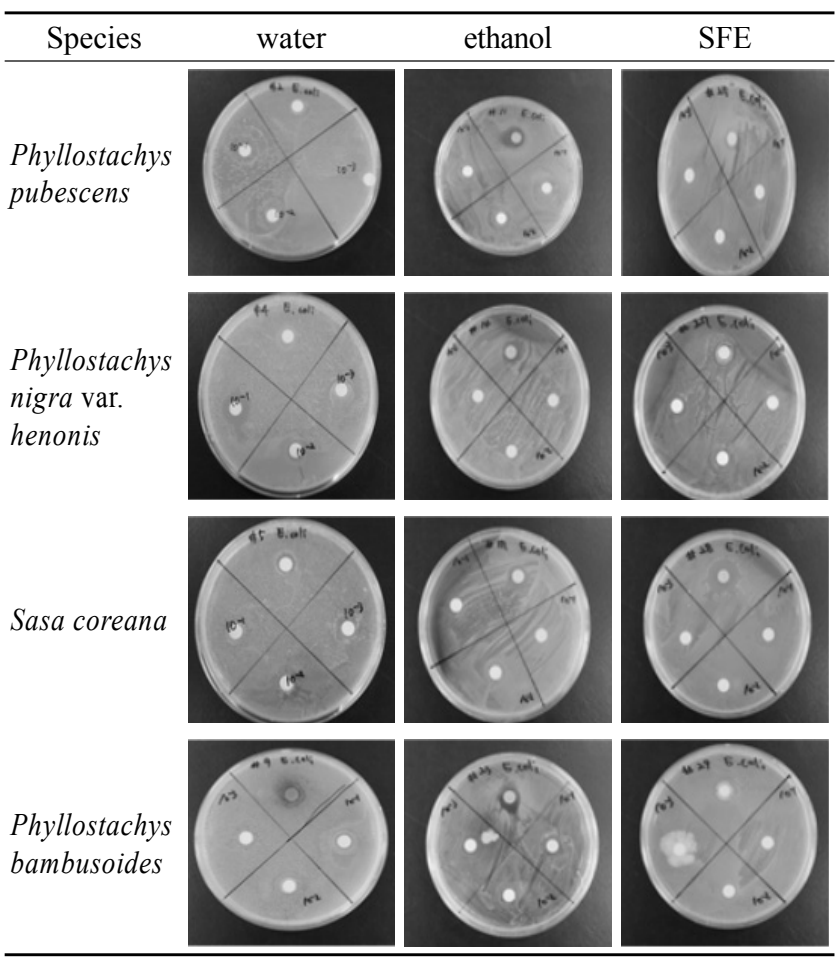

Fig. 2. Comparison of antimicrobial activities against $S$. aureus by different extraction methods in Korean bamboos.

\subsection{DPPH 소거능에 따른 항산화적 특성}

DPPH (1,1-diphenyl-2-picrylhydrazyl)는 항산화물질로부터 전자나 수소를 받아 불가역적으로 안정한 분자를 형성하므 로 전자공여능으로부터 항산화 활성을 추정할 수 있는데 항 산화 활성이 있는 물질과 만나면 radical이 소거되며 이때 의 DPPH 고유의 청남색이 엷어지는 특성이 있고 이 색차를 비색 정량하여 전자공여능력을 측정한다 [22-24]. DPPH를 이용한 유리 라디칼 소거 반응으로 대나무 추출액의 항산화 작용을 측정한 결과, $1 \sim 1000 \mu \mathrm{g} / \mathrm{mL}$ 의 농도에서 농도 의존적 인 항산화 작용을 보였다. 맹종죽의 경우 저농도 $(600 \mu \mathrm{L} / \mathrm{mL}$ 이하)의 농도에서는 용매추출물의 항산화능이 가장 높은 양상을 보였으며, 고농도 $(1,000 \mu \mathrm{L} / \mathrm{mL}$ 이상 $)$ 에서는 초임계 추출물의 항산화력이 지속적으로 증가하였다. 신이대의 경 우는 열수와 용매 추출물이 $600 \mu \mathrm{L} / \mathrm{mL}$ 의 농도를 기준으로 항산화력이 급감하는 반면, 초임계 추출물은 지속적으로 증 가하였다. 왕대의 경우 초임계 추출물이 $300 \mu \mathrm{L} / \mathrm{mL}$ 농도 이후에 항산화력이 급격하게 증가하는 경향을 나타내어, 다 른 죽종의 초임계 추출물과 다른 경향을 나타내어 이에 대한 추후 연구가 필요할 것으로 사료되었다 (Fig. 2). 이러한 결과 
는 대나무 잎으로부터 추출한 폴리페놀류 유도체들이 DPPH 를 이용한 항산화 실험에서 유의한 항산화 작용이 있다는 것이 보고와 유사한 경향을 나타내었다 $[25,26]$. 향후 대나무 초임계 추출물 활용 항산화 소재의 개발은 왕대에서 개발할 수 있는 기초적인 연구 결과로 판단된다.
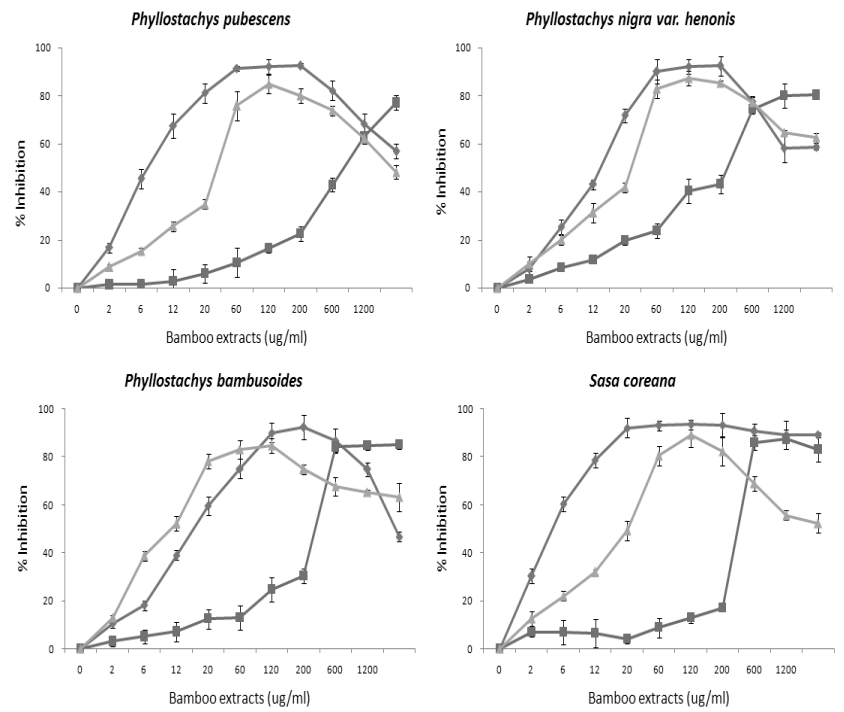

Fig. 3. Antioxidant activities of bamboo extracts in the DPPH radical scavenging activity assay. A solution of $180 \mu \mathrm{L}$ of $100 \mu \mathrm{M}$ DPPH solution in ethanol was gently mixed with $20 \mu \mathrm{L}$ of bamboo extracts for $20 \mathrm{~min}$ and the absorbance was measured at $517 \mathrm{~nm}$. Results are means \pm SD from 3 separate experiments $(\diamond$ : ethanol, $\boldsymbol{\Delta}$ : water, $\mathbf{m}$ : SFE extract).

\section{4. 결론}

국내에서 자생하는 대나무 4종의 향후 미용향장소재로서 의 기능성을 파악하기 위하여 초임계 추출방법을 적용한 대나무 초임계 추출물의 생물학적 특성을 확인하고자 하 였다. 대나무 추출물의 항균성은 전반적으로 ethanol 추출 물이 두 공시균주에 대하여 열수 및 초임계 추출물과 비교 하여 우수한 항균력을 보이는 것으로 나타났다. 그람 음성 균 E.coli에 대한 항균력에서 3종의 대나무 (맹종죽, 솜 대, 왕대)에서 용매추출물이 강한 항균력을 보인 반면에, 신이대의 경우는 초임계 추출물이 다른 추출물에 비하여 가장 강한 항균력을 나타내어 대나무 종류에 따른 차이를 나타내었다. $\mathrm{DPPH}$ 를 이용한 유리 라디칼 소거 반응으로 대나무 추출액의 항산화 작용을 측정한 결과, $1 \sim 1000 \mu \mathrm{g} / \mathrm{mL}$ 의 농도에서 농도 의존적인 항산화 작용을 보였다. 맹종죽의 경우 저농도 $(600 \mu \mathrm{L} / \mathrm{mL}$ 이하)의 농도에서는 용매추출물의 항산화능이 가장 높은 양상을 보였으며, 고농도 $(1,000 \mu \mathrm{L} / \mathrm{mL}$ 이상)에서는 초임계 추출물의 항산화력이 지속적으로 증 가하였다. 이상의 결과로 미루어 볼 때, 국내에서 자생하는 대나무를 이용하여 미용향장소재로 활용하기 위해서는 초 임계 추출방법이 항산화 관련 소재 개발에 유용한 추출방법 이라고 판단된다.
감사

본 연구는 2011년도 광역연계협력사업 3G-Bio 친환경 생물 소재 고도화 사업에 관한 연구의 일부이며, 연구비를 지원한 지식경제부와 전남생물산업진흥재단에 깊이 감사드립니다.

\section{References}

1. Chiu, K. L., Y. C. Cheng, J. H. Chen, C. H. Chang, and P. W. Yang (2002) Supercritical fluids extraction of Ginkgo ginkgolides and flavonoids. J. Supercrit. Fluids 24: 77-87.

2. Lang, Q. and C. M. Wai (2001) Supercritical fluid extraction in herbal and natural product studies-apractical review. Talanta 53: 771-782.

3. Lin, M. C., M. J. Tsai, and K. C. Wen (1999) Supercritical fluid extraction of flavonoids from Scutellariae radix. J. Chromatogr. A 830: 387-395.

4. Zhou, Z. X. (1992) The studies on the chemical constituents of bamboo leaves. Res. Dev. Nat. Prod. 4: 44-51.

5. Zhang, Y. and X. L. Ding (1996) Studies on antioxidative fraction in bamboo leaves and its capacity to scavenge active oxygen radicals. J. Bamboo Res. 15: 17-24.

6. Li, H. Y., J. W. Sun, and S. W. Dai (2003) Study on chemical components of bamboo leaf. Chin. Med. Mat. 26: 562-563.

7. Luo, J. Y. and X. Y. Chen (2003) Study on extracting tea polyphenols from leaf of Indocalamus. Chem. Ind. Forest Prod. 37: $15-19$.

8. Lu, Z. K. and W. Liao (2003) Preliminary determination of chemical components for leaves of Phllostachys pubescens. J. Shanxi Univ. Nat. Sci. Ed. 26: 46-48.

9. Zhang, Y. and Ding, X. L. (1997) Existence of specific amino acid in bamboo leaves and its biological significance. J. Wuxi Univ. Light Ind. 16: 29-32.

10. Tang, L. L. and X. L. Ding (2000) Extraction of bamboo amylase and its biological functions. Devel. Res. Food. 21: 8-10.

11. Xu, G., H. Zhang, and J. H. Dong (2001) Studies on superoxide and hydroxyl radical scavenging capacity of bamboo leaves extracts. J. Nutr. 23: 79-81.

12. Xu, G. and H. Zhang (2001) A comparison of the antimicrobial function of both extracts to bacterium between bamboo leaves and Artemisia anomala S. Moore. Food Sci. Technol. 6: 38.

13. Huang, W., Y. Wang, X. B. Hu, and Yin, J. T. (2002) Study on antimicrobial characteristics of bamboo leaf extracts. Chem. Ind. Forest Prod. 22: 68-70.

14. Li, Y. H., H. M. Liu, Y. F. Yan, D. S. Luo, H. H. Zheng, M. J. Wang, and S. Q. Yao (2002) The inhibitory effect of bamboo leaves extract on implanted Sarcomal 80 tumor. J. Hubei Coll. TCM. 4: 17-19.

15. Zhang, Y., J. F. Shen, Z. Y. Yu, B. Y. Lu, and D. D. Lou (2004) Primary studies on bamboo leaf flavonoids used as anti-aging factor for skin protection. Chem. Ind. For. Prod. 24: 95-100.

16. Chung, D. K. and R. N. Yu (1995) Antimicrobial activity of bamboo leaves extract on microorganisms related to kimchi fermentation. Korean J. Food Sci. Technol. 27: 1035-1038.

17. Kim, J. H. (2003) Cytotoxicity of Sasamorpha purpurascens Extract against HL60 Cells and L1210 Cells with Alterations of ROS Scavenging Enzymes Activities. MS Thesis. Sangmyung University, Seoul, Korea.

18. Jeong, E. Y. (2006) Effect of the Sasa borealis Leaves Extract on Metabolic Syndrome in C57BL/6J Mice Fed a High Fat Diet. 
MS Thesis. Chonnam National University, Gwangju, Korea.

19. Kim E. Y. (2007) Effect of the Sasa borealis leaves extract on cytokine levels in C57/BL6J mice. MS Thesis. Chonnam National University, Gwangju, Korea.

20. Hwang, J. Y. and J. S. Han (2007) Inhibitory effects of Sasa borealis leaves extracts on carbohydrate digestive enzymes and postprandial hyperglycemia. J. Korean Soc. Food Sci. Nutr. 36: 989-994.

21. Park, S. J. and D. H. Oh (2003) Free radical scavenging effect of seed and skin extracts of black olympia grape (Vitis labruscana L.). Korean J. Food Sci. Technol. 35: 121-124.

22. Cha, H. S., M. S. Park, and K. M. Park (2001) Physiological activities of Rubus coreanus Miquel. Korean J. Food Sci. Technol. 33: 409-415.
23. Lee, M. J. and G. S. Moon (2003) Antioxidative effects of Korean bamboo tree, wang-dae, som-dae, maengjong-juk and o-juk. Korean J. Food. Sci. Technol. 35: 1226-1232.

24. Park, H. S., J. H. Lim, H. J. Kim, H. J. Choi, and I. S. Lee (2007) Antioxidant flavone glycosides from the leaves of Sasa borealis. Arch. Pharm. Res. 30: 161-166.

25. Kweon, M. H., H. J. Hwang, and H. C. Sung (2001) Identification and antioxidant activity of novel chlorogenic acid derivatives from bamboo (Phyllostachys edulis). J. Agric. Food Chem. 49: 4646-4655.

26. Perez, G. R. M., S. R. Vargas, M. F. J. Martinez, and R. I. I. Cordova (2004) Antioxidant and free radical scavenging activities of 5,7,3'-trihydroxy-3,6,4'-trimethoxy flavone from Brickellia veronicaefolia. Phytother. Res. 18: 428-430. 